$14^{\text {th }}$ Conf. Agric. Develop. Res., Fac. of Agric., Ain Shams Univ.,

March, 2019, Cairo, Egypt

Special Issue, 27(1), 659 - 671, 2019

Website: http://strategy-plan.asu.edu.eg/AUJASCl/

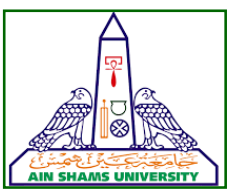

\title{
EFFECT OF FOLIAR APPLICATION WITH ALGAE AND MORINGA LEAVES EXTRACTS ON VEGETATIVE GROWTH, LEAF MINERAL CONTENTS, YIELD AND CHEMICAL FRUIT QUALITY OF PICUAL OLIVE TREES
}

$[61]$

\author{
Hassan A.M. ${ }^{1 *}$, Abd-Alhamid ${ }^{2}$ N., Rawheya B.M.A. Aly ${ }^{2}$, Hassan ${ }^{1}$ H.S.A. \\ and Laila F. Hagagg ${ }^{1}$ \\ 1. Pomology Dept., National Research Center, Dokki, Giza, Egypt \\ 2. Horticulture Dept., Fac. of Agric., Ain Shams Univ., P.O. Box 68, Hadayek Shoubra, 11241, \\ Cairo, Egypt
}

*Corresponding author: ahmed.m.hasan89@gmail.com

Received 13 January, 2019, Accepted 5 February, 2019

\section{ABSTRACT}

This study was carried out during 2017 and 2018 seasons on adult Picual olive cv. (8 years old) in a private orchard located at Cairo Ismailia Desert Road, (about $80 \mathrm{Km}$ from Cairo), Ismailia Governorate, Egypt. Trees are grown in sandy soil, under drip irrigation system, uniform in shape and received the common horticultural practices, therefore, this work aims to study the effect of spraying different concentrations and dates spray of algae and moringa leaf extract (MLE) for tow times on the vegetative growth, leaf mineral contents, yield and fruit chemical properties of Picual olive trees. Results indicated that all different spraying treatments of algae and moringa extract at different spraying dates had a positive effect on vegetative growth, leaf mineral contents, fruit set, yield and fruit chemical properties in comparison with the control. Treatments of algae extract at $0.4 \%+$ moringa leaves extract at $2 \%$ and algae extract at $0.4 \%+$ moringa leaves extract at $4 \%$ were the most effective treatments to increase vegetative growth, improve leaf mineral content, fruit set, yield and oil content. Thus, these treatments can be recommended for commercial use under similar conditions

Keywords: Olive trees, Picual, Algae extract, Moringa leaves extract, Vegetative growth, Leaf mineral content, Yield, Fruit quality

\section{INTRODUCTION}

Olive tree (Olea europaea L.) is one of the oldest agricultural crops of remarkable economic and cultural importance in the Mediterranean Basin, it also represents as a widely distributed fruit tree in the world (FAO, 2017). The olive is an evergreen tree, belongs to family Oleaceae and includes many cultivars which are used for pickling and oil extraction. In addition, olive is well adapted to a wide range of growing conditions and soils. According to Ministry of Agriculture and Land Reclamation (M.A.L.R., 2016) the cultivated area with olive was increased gradually and reached 243,182 feddans produced 874,748 tons with average of 3.59 tons per feddan. Picual olive cv. was introduced from Spain to Egypt and considered one of the best and main widely planted cultivar in Egypt. Moreover, most of the olive trees in Egypt are planted in new reclaimed areas; the majority of these areas are sandy soil that lacked of macro and micro-nutrients. In addition, the successful orchard management practices are directed toward obtaining a suitable yield with good fruit quality. One of the most important cultural practices is the mineral nutrition especially in the new reclaimed land. So, foliar spraying application has a high efficiency to satisfy plant requirement with nutrient elements quickly, directly and economic than soil application fertilizer.

Application of seaweed extract had been known for many years as soil fertilizers and plant growth supplements in agriculture giving beneficial 
effects including, increase in crop yield, fruit yield, improving fruit fresh weight and high chlorophyll levels in the leaves of the plant, improving nutrient uptake by the crops. Algae extract as a new biofertilizer containing $\mathrm{N}, \mathrm{K}, \mathrm{P}, \mathrm{Mg}, \mathrm{Ca}$, and $\mathrm{S}$ as well as $\mathrm{Fe}, \mathrm{Zn}, \mathrm{Mn}, \mathrm{Mo}, \mathrm{Cu}$, and $\mathrm{Co}$, polyamines, vitamins and some growth regulators was applied to improve nutritional status, vegetative growth, yield and fruit quality in different orchards as well as vineyards (Abd El-Migeed et al 2004) on olive seedling (Spinelli et al 2009 and El-Sharony et al 2015) on mango trees. The mechanisms effects of algae extract on cell metabolism are observed mainly through the physiological action of macro and micro nutrients, vitamins, amino acids, and growth regulators which affect cellular metabolism in treated plants that leading to enhance growth and crop yield (Abd El-Motty and Abd El-migeed 2010). Liquid extracts obtained from seaweeds have gained importance as foliar sprays for several crops (Bokil et al 1974) because of their extract contain growth promoting hormones (IAA and IBA), cytokinins and trace elements $(\mathrm{Fe}, \mathrm{Cu}, \mathrm{Zn}, \mathrm{Co}, \mathrm{Mo}$, $\mathrm{Mn}$ and $\mathrm{Ni}$ ) as well as vitamins and amino acids (Zodape et al 2011). When aqueous extract of seaweeds applied as a foliar spray on Zizyphus mauritiana showed an increase in yield and quality of vegetable crops (Rama Rao, 1991). Applying seaweed extract increased the response of different growth parameters and yield responses of watermelon (Abdel-Mawgoud et al 2010). In this respect, Shehata et al (2011) on Celeriac plants, Fawzy et al (2012b) on Chinese garlic plants, Hernández et al (2013) and Shabana et al (2015) on tomato plants found that foliar spraying of seaweed extract gave the highest values of vegetative growth, yield and fruit quality. However, Ghurbat (2013) on sweet pepper plants reported that spraying seaweed extract led to positive significant difference in plant height $(\mathrm{cm})$, leaves chlorophyll content $\%$ and total yield as well as fruit diameter, fruit length, fruit dry weight, fruit weight, vitamin C, TSS \%, yield per plant and total yield as compared to control plants.

Moringa oleifera belongs to family Moringaceae which is considered the most widely cultivated tropical trees (Shahzad et al 2013). The moringa leaf extract (MLE) is considered as a natural plant growth regulator where, it is a source of zeatin (a natural derivative of cytokines), proteins, phenols, vitamin $\mathrm{E}$, ascorbic acid, essential amino acids and several mineral elements and making it as a potential natural growth stimulant, as mentioned by Howladar (2014) and Rady et al (2015). Other reports showed that moringa extract plays a role as a plant hormone which enhances vegetative growth and yield of crops. The frequent excessive use of chemical inputs have been accused for adverse effects on the quality of environment because they have potentials to disturb the ecological balance of soils and make plants even more susceptible to pests and diseases (Fawzy et al 2012a). Now there is an increasing demand for sound and ecologically compatible and techniques for environment friendly in agriculture, able to provide enough food for the growing human population, retaining quality of soil and improving the quantity and quality of agricultural products (Russo et al 2012). Therefore, this work is aimed to investigate the effect spraying different of concentrations and spraying dates of algae and moringa leaf extract (MLE) on the growth, leaf mineral contents, yield and fruit quality of Picual olive trees.

\section{MATERIAL AND METHODS}

This study was carried out during two successive seasons (2017 and 2018) in a private orchard located at Cairo-Ismailia Desert Road (about 80 $\mathrm{Km}$ from Cairo), Ismailia governorate, Egypt. The study was conducted on 8 years old olive trees of Picual cv., planted at $4 \times 6 \mathrm{~m}$ apart grown in sandy soil, under drip irrigation system. The selected trees were uniformed in shape and received the common horticultural practices. The orchard soil analysis are given in Table (1) and the water irrigation analysis are given in Table (2) according to procedures which are outlined by Wild et al (1985).

Table 1. Some physical and chemical properties of the orchard soil

\begin{tabular}{|c|c|c|c|}
\hline \multirow{2}{*}{ Parameters } & \multicolumn{3}{|c|}{ Depth of simple (cm) } \\
\cline { 2 - 4 } & $\begin{array}{c}\text { Surface } \\
\text { sample }\end{array}$ & $\begin{array}{c}\text { 30 cm } \\
\text { depth }\end{array}$ & $\begin{array}{c}\mathbf{6 0} \mathbf{~ c m} \\
\text { depth }\end{array}$ \\
\hline $\mathbf{p H}$ & 8.02 & 8.70 & 8.11 \\
$\mathrm{EC}(\mathbf{d S m}-1)$ & 3.80 & 0.80 & 1.70 \\
& \multicolumn{3}{|c|}{ Soluble cations (meq V) } \\
$\mathbf{C a}^{++}$ & 6.00 & 2.50 & 3.00 \\
$\mathbf{M g}^{++}$ & 4.00 & 1.50 & 1.50 \\
$\mathrm{Na}^{+}$ & 28.60 & 4.40 & 12.90 \\
$\mathbf{K}^{+}$ & 0.12 & 0.14 & 0.78 \\
& \multicolumn{3}{|c|}{ Soluble anions (meqV) } \\
$\mathbf{C O}_{3}^{-}$ & - & - & - \\
$\mathbf{H C O}^{-}$ & 4.40 & 2.40 & 2.00 \\
$\mathbf{C l}^{-}$ & 27.20 & 5.00 & 13.00 \\
$\mathbf{S O}_{4}{ }^{-}$ & 7.12 & 1.14 & 3.18 \\
\hline
\end{tabular}



mineral contents, yield and chemical fruit quality of Picual olive trees

Table 2. Chemical characteristics of the used water well for the present study

\begin{tabular}{|c|c|}
\hline parameters & Values \\
\hline $\mathrm{pH}$ & 7.49 \\
$\mathrm{EC}(\mathrm{dSm}-1)$ & 4.40 \\
\hline \multicolumn{2}{|c|}{ Soluble cations (meq/l) } \\
\hline $\mathrm{Ca++}$ & 7.50 \\
$\mathrm{Mg}++$ & 5.00 \\
$\mathrm{Na}+$ & 33.1 \\
$\mathrm{~K}+$ & 0.16 \\
\hline \multicolumn{2}{|c|}{$\mathrm{Soluble}^{-2}$ anions (meq/l) } \\
\hline $\mathrm{CO}_{3}{ }^{-2}$ & - \\
$\mathrm{HCO}_{3}^{-}$ & 1.60 \\
$\mathrm{Cl}^{-}$ & 40.00 \\
$\mathrm{SO}_{4}^{-2}$ & 4.16 \\
\hline
\end{tabular}

\section{Preparation of moringa leaves extract (MLE)}

The new shoots of the moringa plants were harvested at 35 days after emergence. An amount of $20 \mathrm{~g}$ of young moringa leaves was mixed with $675 \mathrm{ml}$ of $80 \%$ ethanol as suggested by Makker and Becker (1996). The suspension was grind and stirred using a homogenizer to maximize the amount of the extract. The solution was then filtered by wringing the solution using a mutton cloth. The solution was re-filtered using No. 2 whatman filter paper using the method developed by Fuglie (2000). The extract was used within five hours from cutting and extracting (if not ready to be used, the extract or solution prepared was stored at $0^{\circ} \mathrm{C}$ and only taken out when needed for use).

Algae extract obtained from Union for Biotechnology Unit, NRC and chemical constituents are shown in Table (3).

Table 3. Chemical composition of some macro- and micronutrients and growth hormones of blue green algae extract used in the experiment study

\begin{tabular}{|c|c|c|c|c|c|c|c|c|c|c|}
\hline \multirow{2}{*}{ Moisture \% } & Crude pro- & \multicolumn{4}{|c|}{ Macronutrients (\%) } & \multicolumn{3}{c|}{ Micronutrients (ppm) } \\
\cline { 3 - 10 } & tein \% & $\mathbf{N}$ & $\mathbf{P}$ & $\mathbf{K}$ & $\mathbf{C a}$ & $\mathbf{M g}$ & $\mathbf{F e}$ & $\mathbf{Z n}$ & $\mathbf{M n}$ & $\mathbf{C u}$ \\
\hline 4.77 & 58.25 & 11.2 & 1.65 & 0.88 & 0.33 & 0.01 & 1936 & 33 & 73 & 14 \\
\hline \multicolumn{8}{|c|}{ Growth hormones (\%) } \\
\hline Cytokinins & Betanin & Alginic & Zeatine & Mannitol & \multicolumn{2}{c|}{ Oligo sccharide } \\
\hline 0.001 & 0.03 & \multicolumn{2}{|c|}{4.8} & \multicolumn{2}{c|}{0.002} & 0.001 & \multicolumn{2}{c|}{2.9} \\
\hline
\end{tabular}

The selected trees were sprayed with algae and moringa leaf extract at different concentrations and dates (i.e. mid of November or mid of December) each date had a separate group of trees during the two studied seasons as follow:

1. Control treatment (spray with water only)

2. Tree spray with algae extract at $0.2 \%$.

3. Tree spray with algae extract at $0.4 \%$.

4. Tree spray with moringa leaves extract (MLE) at $2 \%$.

5. Tree spray with moringa leaves extract at (MLE) $4 \%$.

6. Tree spray with algae extract at $0.2 \%+$ moringa leaves extract at $2 \%$.

7. Tree spray with algae extract at $0.2 \%+$ moringa leaves extract at $4 \%$.

8. Tree spray with algae extract at $0.4 \%+$ moringa leaves extract at $2 \%$.

9. Tree spray with algae extract at $0.4 \%+$ moringa leaves extract at $4 \%$.
Both group of trees which sprayed at November or December received other two spraying dates i.e. the first at full bloom and the second after fruit set. Each treatment was represented by three replicates (one tree per replicate) which were chosen randomly and on early November of each season, twenty healthy one-year old shoots well distributed around the canopy were randomly selected and labeled (5 shoots for each direction) for carrying out the following measurements:

\section{Vegetative parameters}

At the end of each growing season, during first week of September the following characteristics were measured.

1- Number of leaves per shoot

2- Leaf area $\left(\mathrm{cm}^{2}\right)$ according to Ahmed and Morsy (1999) using the following equilibration:

Leaf area $=0.53$ (length $\mathrm{x}$ width) +1.66 . 


\section{Leaf mineral contents}

At the end of each growing season, during first week of September, leaf samples were collected, washed and dried at $70^{\circ} \mathrm{C}$ until constant weight and then grind for determination the following nutrient elements (as percentage of dry weight):

1- Nitrogen: Using the modified micro kjeldahl method as lined by Pregl (1945).

2- Phosphorus: Was estimated as the method described by Chapman and Pratt (1961).

3- Potassium: Was determined using Flame photometer according to Brown and Lilleland (1946).

Fruit Set: Fruit set percentage as number of fruits / meter after 60 days from full bloom as final fruit set was calculated as follow:

Final fruit set $(\%)=[$ Number of fruit set $(60$ days after full bloom) / shoot length $(\mathrm{cm})] \times 100$

Fruit Yield: Fruits were harvested at ripening stage on end of October in 2017 and 2018 years. Each individual tree was harvested manually and weight of fruits/tree for all trees was measured. Average yield $(\mathrm{kg})$ /tree was determined for each treatment.

\section{Chemical properties of fruit}

1- Fruit oil content \%: Oil percentage was determined in the fruit flesh on dry weight basis using soxhlet oil extraction apparatus with Hexane $60-80^{\circ} \mathrm{C}$ boiling point, according to Banat et al (2013).

2-Acid value: It was determined according to the Deffenbacker and Pocklingon (1992), since five grams of oil were accurately weighed in $250 \mathrm{ml}$ dry conical flask with about $100 \mathrm{ml}$ of neutralized $50 \%$ ethanol $+50 \%$ petroleum ether to dissolve the oily sample. Acidity of the sample was determined by titration with $0.1 \mathrm{~N}$ of potassium hydroxide solution in the presence of phenolphthalein as an indicator. The acid value was calculated according to the following equation.

Acid percentage $=\frac{\mathrm{V} \times \mathrm{N} \times 5.61 \times 100}{\text { Weight of sample }}$

Where,

$\mathrm{V}=$ Volume of $\mathrm{KOH}$ solution

$\mathrm{N}=$ Normality of potassium hydroxide solution
3-The peroxide value: The peroxide value was determined according to Jacobs (1959) by dissolving $5 \mathrm{~g}$ of the oil in a mixture consisting of $60 \%$ glacial acetic acid $+40 \%$ chloroform. The solution was treated with approximately $0.5 \mathrm{ml}$ of saturated solution of potassium iodide in glass stoppard flask. The flask was shacked in rotary for exactly two minutes, after which $30 \mathrm{ml}$ of distilled water was added, and the liberated iodine was titrated with $0.01 \mathrm{~N}$ sodium thiosulfate using $1 \%$ of starch solution as external indicator.

The results were calculated in mill moles per kilogram oil according to the following equation.

Peroxide value $=\frac{0.5 \times \mathrm{N} \times \mathrm{V} \times 100}{\text { Weight of sample }}$

Where,

$\mathrm{N}=$ Normality of sodium thiosulfate solution

$\mathrm{V}=$ Volume in $\mathrm{ml}$. of sod. thiossulfate needed for titration

4-lodine value: The degree of instauration of oil was determined by measuring the amount of halogen absorbed by the oil as stated in Deffenbacker and Pocklingon (1992), since $0.1-0.5 \mathrm{~g}$ of oil was dissolved in $10 \mathrm{ml}$ of chloroform and $25 \mathrm{ml}$ of Hanus iodine solution were added. After $30 \mathrm{~min}$. $10 \mathrm{ml}$ of $15 \%$ potassium iodine solution and 100 $\mathrm{ml}$ of freshly boiled cooled distilled water were added. The liberated iodine was titrated with $0.1 \mathrm{~N}$ of sodium thiosulfate using starch indicator.

lodine value $=$

$$
\frac{\left(V_{1}-V_{2}\right) \times N \times 12.69}{\text { Weight of sample }}
$$

Where,

$\mathrm{N}=$ Normality of sodium thiosulfate solution

$\mathrm{V}_{1}=$ Volume in $\mathrm{ml}$. of sod. Thiossulfate needed for titration Blank

$\mathrm{V}_{2}=$ Volume in $\mathrm{ml}$. of sod. Thiossulfate needed for titration sample

\section{Experimental Design and Statistical Analysis}

This work was conducted as factorial experiment. Treatments were arranged in a completely randomized block design with three replicates for each treatment. The statistical analysis of the data was performed using MSTAT statistical program. The data was analyzed by ANOVA to determine 
the significance of the treatments and the least significant difference (LSD) was used for treatment means comparisons at $p=0.05$ according to Snedecor and Cochran (1980).

\section{RESULTS}

\section{Vegetative Parameters}

Results presented in Table (4) show that number of leaves per shoot was significantly affected by spraying algae and moringa leaves extract individually or in combination at both spraying dates in two studied seasons. As for tree spray with algae extract at $0.2 \%+$ moringa leaves extract at $4 \%$ (T6) and tree spray with algae extract at $0.4 \%+$ moringa leaves extract at $4 \%$ (T8), recorded the highest value in this respect, since it was 41.08 and 45.63 in both studied seasons. Meanwhile, the lowest one was under control treatment (33.35 and 32.44) during the first and second seasons, respectively. Regarding the time of foliar application it observed that November spraying date was significantly higher value (37.54) than December one (36.85) in the first season, meanwhile in the second one, there was no significant differences between spraying dats. Concerning interaction effect, trees sprayed with algae extract at $0.2 \%+$ moringa leaves extract at 4\% (T6) in December recorded the highest significant value in this respect. On the other hand, trees sprayed with algae extract at $0.4 \%+$ moringa leaves extract at $4 \%$ (T8) in November and December scored the highest value in this respect since it was 45.66 and 45.60 for November and December, respectively in the second season.

Concerning leaf area results in the same table reveal that all different treatments increased leaf area as compared with control treatment. Tree spray with algae extract at $0.4 \%+$ moringa leaves extract at $4 \%$ (T8) recorded the highest leaf area $\left(4.20\right.$ and $\left.4.80 \mathrm{~cm}^{2}\right)$ in the first and second seasons, respectively. Meanwhile, the value one was under control treatment $\left(3.71\right.$ and $\left.3.73 \mathrm{~cm}^{2}\right)$ in the first and second seasons, respectively. On the other hand, in respect to the time of foliar application it observed that November spraying date was significantly higher $\left(4.04 \mathrm{~cm}^{2}\right)$ than December one $\left(3.93 \mathrm{~cm}^{2}\right)$ in the first season, meanwhile in the second one there was no significant differences for spraying time. As for interaction effect, trees sprayed with algae extract at $0.4 \%+$ moringa leaves extract at 4\% (T8) in December recorded the highest value in this respect $(4.31$ and 4.92 $\mathrm{cm}^{2}$ ) in the two studied seasons, respectively.

Table 4. Effect of foliar applications with algae and moringa leaves extracts on vegetative growth of Picual olives in 2017 and 2018 seasons.

\begin{tabular}{|c|c|c|c|c|c|c|c|c|c|c|c|c|}
\hline \multirow{4}{*}{ Treat. } & \multicolumn{6}{|c|}{ No. of leaves / shoot } & \multicolumn{6}{|c|}{ Leaf Area $(\mathrm{cm} 2)$} \\
\hline & \multicolumn{3}{|c|}{2017} & \multicolumn{3}{|c|}{2018} & \multicolumn{3}{|c|}{2017} & \multicolumn{3}{|c|}{2018} \\
\hline & \multicolumn{2}{|c|}{ Spraying date } & \multirow{2}{*}{ Mean } & \multicolumn{2}{|c|}{ Spraying date } & \multirow{2}{*}{ Mean } & \multicolumn{2}{|c|}{ Spraying date } & \multirow{2}{*}{ Mean } & \multicolumn{2}{|c|}{ Spraying date } & \multirow{2}{*}{ Mean } \\
\hline & Nov. & Dec. & & Nov. & Dec. & & Nov. & Dec. & & Nov. & Dec. & \\
\hline Cont. & $32.86 \mathrm{gh}$ & $33.83 f g h$ & $33.35 \mathrm{~F}$ & $32.07 n$ & $32.80 \mathrm{~m}$ & $32.44 \mathrm{I}$ & $3.71 \mathrm{~g}$ & $3.76 \mathrm{~g}$ & $3.73 \mathrm{D}$ & $3.73 \mathrm{i}$ & $3.74 \mathrm{i}$ & $3.74 \mathrm{G}$ \\
\hline T1 & $38.00 \mathrm{~d}$ & $40.25 \mathrm{c}$ & $39.12 \mathrm{~B}$ & 33.251 & $32.75 \mathrm{~m}$ & $33.00 \mathrm{H}$ & $3.95 \mathrm{de}$ & $3.85 f$ & $3.90 \mathrm{C}$ & $4.41 \mathrm{e}$ & $4.04 \mathrm{~g}$ & $4.23 \mathrm{D}$ \\
\hline T2 & $37.25 \mathrm{de}$ & $34.33 \mathrm{fg}$ & 35.79DE & $35.60 \mathrm{j}$ & $36.00 \mathrm{i}$ & $35.80 \mathrm{G}$ & $4.26 \mathrm{a}$ & $3.98 \mathrm{~cd}$ & $4.11 \mathrm{~B}$ & $4.23 \mathrm{f}$ & $3.91 \mathrm{~h}$ & $4.07 \mathrm{E}$ \\
\hline T3 & $44.24 b$ & $33.75 \mathrm{fgh}$ & 38.99 B & $41.50 \mathrm{e}$ & $40.00 \mathrm{~g}$ & $40.75 \mathrm{E}$ & $3.97 d$ & $3.78 \mathrm{f}$ & $3.87 \mathrm{C}$ & $4.41 \mathrm{e}$ & $3.99 \mathrm{~g}$ & $4.20 \mathrm{D}$ \\
\hline T4 & $38.00 \mathrm{~d}$ & $37.67 \mathrm{de}$ & $35.20 \mathrm{E}$ & $42.60 \mathrm{~d}$ & $43.00 \mathrm{c}$ & $42.80 \mathrm{~B}$ & $4.00 \mathrm{~cd}$ & 3.86 ef & $3.92 \mathrm{C}$ & $4.23 f$ & $4.81 \mathrm{~b}$ & $4.52 \mathrm{C}$ \\
\hline T5 & $38.33 d$ & $36.25 \mathrm{e}$ & $37.29 \mathrm{C}$ & $40.37 \mathrm{f}$ & $44.50 \mathrm{~b}$ & $42.43 \mathrm{C}$ & $4.07 \mathrm{bc}$ & $3.82 f$ & $3.95 \mathrm{C}$ & $4.57 \mathrm{~d}$ & $4.58 \mathrm{~d}$ & $4.58 \mathrm{~B}$ \\
\hline T6 & $33.67 f g h$ & $48.50 \mathrm{a}$ & $41.08 \mathrm{~A}$ & $37.00 \mathrm{~h}$ & $35.20 \mathrm{k}$ & $36.10 \mathrm{~F}$ & $4.20 \mathrm{a}$ & 3.91 ef & $4.06 \mathrm{~B}$ & $4.19 f$ & $4.20 \mathrm{f}$ & 4.19 D \\
\hline $\mathrm{T7}$ & $37.75 \mathrm{de}$ & $34.66 \mathrm{f}$ & $36.21 \mathrm{D}$ & $42.37 \mathrm{~d}$ & $41.30 \mathrm{e}$ & $41.83 \mathrm{D}$ & $4.08 \mathrm{~b}$ & $4.18 \mathrm{a}$ & $4.13 \mathrm{~B}$ & $3.78 \mathrm{i}$ & $3.99 \mathrm{~g}$ & $3.88 \mathrm{~F}$ \\
\hline T8 & 37.77 de & $32.41 \mathrm{~h}$ & $37.72 \mathrm{C}$ & $45.66 \mathrm{a}$ & $45.60 \mathrm{a}$ & $45.63 \mathrm{~A}$ & $4.09 \mathrm{~b}$ & $4.31 \mathrm{a}$ & $4.20 \mathrm{~A}$ & $4.69 \mathrm{c}$ & $4.92 \mathrm{a}$ & $4.80 \mathrm{~A}$ \\
\hline Mean & $37.54 A^{*}$ & $36.85 \mathrm{~B}^{*}$ & & $38.93 A^{*}$ & $39.02 A^{*}$ & & $4.04 \mathrm{~A}^{*}$ & $3.93 \mathrm{~B}^{\star}$ & & $4.25 \mathrm{~A}^{*}$ & $4.24 A^{*}$ & \\
\hline
\end{tabular}

Mean in each column, row or interaction with similar letter(s) are not significantly different at $5 \%$ level.

T1 = Algae extract at $0.2 \%$, T2 = Algae ext. at $0.4 \%$, T3 = Moringa leaves ext. "MLE" at 2\%, T4 =MLE at $4 \%$, T5 = Algae ext. at $0.2 \%+$ MLE at $2 \%$, T6 = Algae ext. at $0.2 \%+$ MLE at $4 \%$, T7 = Algae ext. at $0.4 \%+$ MLE at $2 \%$, T8= Algae ext. at $0.4 \%+$ MLE at $4 \%$. 


\section{Leaf mineral contents}

Results presented in Table (5) illustrate the effect of different spraying treatments alone or in combination at different dates on leaf nitrogen, phosphorus and potassium contents of Picual olive during the two seasons of the study. Nitrogen content in the leaves was significantly affected by different spraying concentrations and dates in both seasons. Trees sprayed with algae extract at $0.2 \%+$ moringa leaves extract at $2 \%$ (T5) and trees sprayed with algae extract at $0.4 \%+$ moringa leaves extract at $2 \%$ (T7) gave the highest leaf content of $\mathrm{N}(2.14$ and $2.19 \%)$ in both study sea- sons respectively, while control treatment gave the lowest leaf content of $N(1.71$ and $1.53 \%)$ in the two seasons. As for date of spray, it can be concluded that treatments sprayed at December produced the higher value (1.99 and $2.02 \%$ ) as compared with November (1.83 and $1.93 \%$ ) in the first and second seasons, respectively. Regard to the interaction effect, trees sprayed with algae extract at $0.2 \%+$ moringa leaves extract at $4 \%$ (T6) and trees sprayed with algae extract at $0.4 \%+$ moringa leaves extract at $2 \%$ (T7) recorded the highest value $(2.39$ and $2.35 \%)$ in this respect in both study seasons, respectively.

Table 5. Effect of foliar applications with algae and moringa leaves extracts on some macro elements content of Picual olive leaves in 2017 and 2018 seasons.

\begin{tabular}{|c|c|c|c|c|c|c|c|c|c|c|c|c|}
\hline \multirow{4}{*}{ Treat. } & \multicolumn{6}{|c|}{$\mathrm{N}(\%)$} & \multicolumn{6}{|c|}{$\mathbf{P}(\%)$} \\
\hline & \multicolumn{3}{|c|}{2017} & \multicolumn{3}{|c|}{2018} & \multicolumn{3}{|c|}{2017} & \multicolumn{3}{|c|}{2018} \\
\hline & \multicolumn{2}{|c|}{ Spraying date } & \multirow{2}{*}{ Mean } & \multicolumn{2}{|c|}{ Spraying date } & \multirow{2}{*}{ Mean } & \multicolumn{2}{|c|}{ Spraying date } & \multirow{2}{*}{ Mean } & \multicolumn{2}{|c|}{ Spraying date } & \multirow{2}{*}{ Mean } \\
\hline & Nov. & Dec. & & Nov. & Dec. & & Nov. & Dec. & & Nov. & Dec. & \\
\hline Cont. & $1.71 \mathrm{ab}$ & $1.72 a b$ & $1.71 \mathrm{H}$ & $1.53 \mathrm{~d}$ & $1.53 \mathrm{~d}$ & $1.53 \mathrm{I}$ & $0.20 \mathrm{a}$ & $0.21 \mathrm{a}$ & $0.20 \mathrm{E}$ & $0.21 \mathrm{a}$ & $0.22 \mathrm{a}$ & $0.21 \mathrm{C}$ \\
\hline T1 & $1.77 \mathrm{ab}$ & $1.78 a b$ & $1.77 \mathrm{G}$ & $1.90 \mathrm{bcd}$ & $1.76 \mathrm{~cd}$ & $1.83 \mathrm{H}$ & $0.21 \mathrm{a}$ & $0.22 \mathrm{a}$ & $0.21 \mathrm{CD}$ & $0.22 \mathrm{a}$ & $0.22 \mathrm{a}$ & $0.22 B C$ \\
\hline T2 & $1.75 a b$ & $2.00 a b$ & $1.87 \mathrm{E}$ & $1.95 \mathrm{a}-\mathrm{d}$ & $1.81 \mathrm{~cd}$ & $1.88 \mathrm{G}$ & $0.23 \mathrm{a}$ & $0.23 \mathrm{a}$ & $0.23 \mathrm{~A}$ & $0.24 \mathrm{a}$ & $0.23 \mathrm{a}$ & $0.23 A B$ \\
\hline T3 & 1.47 b & $2.12 a b$ & $1.80 \mathrm{~F}$ & $1.99 \mathrm{abc}$ & $2.08 \mathrm{abc}$ & $2.03 \mathrm{E}$ & $0.21 \mathrm{a}$ & $0.23 a$ & $0.22 \mathrm{BC}$ & $0.23 a$ & $0.21 \mathrm{a}$ & $0.22 B C$ \\
\hline T4 & $2.14 \mathrm{ab}$ & $1.95 a b$ & $2.04 \mathrm{C}$ & $2.08 a b c$ & $2.10 \mathrm{abc}$ & $2.09 \mathrm{D}$ & $0.21 \mathrm{a}$ & $0.24 \mathrm{a}$ & $0.22 \mathrm{AB}$ & $0.24 \mathrm{a}$ & $0.22 \mathrm{a}$ & $0.23 A B$ \\
\hline T5 & $2.23 \mathrm{a}$ & $2.05 a b$ & $2.14 \mathrm{~A}$ & $2.04 \mathrm{abc}$ & $2.31 \mathrm{ab}$ & $2.17 \mathrm{~B}$ & $0.21 \mathrm{a}$ & $0.20 \mathrm{a}$ & $0.20 \mathrm{E}$ & $0.23 \mathrm{a}$ & $0.23 \mathrm{a}$ & $0.23 A B$ \\
\hline T6 & $1.83 a b$ & $2.39 a$ & $2.11 \mathrm{~B}$ & $1.81 \mathrm{~cd}$ & $2.08 \mathrm{abc}$ & $1.95 \mathrm{~F}$ & $0.21 \mathrm{a}$ & $0.21 \mathrm{a}$ & $0.21 \mathrm{D}$ & $0.24 \mathrm{a}$ & $0.23 \mathrm{a}$ & $0.23 A B$ \\
\hline T7 & $1.74 a b$ & $1.84 a b$ & $1.79 \mathrm{~F}$ & $2.04 a b c$ & $2.35 \mathrm{a}$ & $2.19 \mathrm{~A}$ & $0.22 \mathrm{a}$ & $0.22 \mathrm{a}$ & $0.21 \mathrm{CD}$ & $0.24 \mathrm{a}$ & $0.24 \mathrm{a}$ & $0.24 \mathrm{~A}$ \\
\hline T8 & $1.78 \mathrm{ab}$ & $2.13 a b$ & $1.96 \mathrm{D}$ & $2.08 \mathrm{abc}$ & $2.17 \mathrm{abc}$ & $2.13 \mathrm{C}$ & $0.22 \mathrm{a}$ & $0.23 a$ & $0.22 A B C$ & $0.25 \mathrm{a}$ & $0.24 \mathrm{a}$ & $0.24 \mathrm{~A}$ \\
\hline Mean & $1.83 \mathrm{~B}^{\star}$ & $1.99 \mathrm{~A}^{\star}$ & & $1.93 \mathrm{~B}^{\star}$ & $2.02 \mathrm{~A}^{\star}$ & & $0.21 \mathrm{~B}^{\star}$ & $0.22 A^{*}$ & & $0.23 A^{*}$ & $0.22 A^{*}$ & \\
\hline \multirow{4}{*}{ Treat. } & \multicolumn{12}{|c|}{$\mathrm{K}(\%)$} \\
\hline & \multicolumn{6}{|c|}{2017} & \multicolumn{6}{|c|}{2018} \\
\hline & \multicolumn{4}{|c|}{ Spraying date } & \multirow{2}{*}{\multicolumn{2}{|c|}{ Mean }} & \multicolumn{4}{|c|}{ Spraying date } & \multirow{2}{*}{\multicolumn{2}{|c|}{ Mean }} \\
\hline & \multicolumn{2}{|c|}{ Nov. } & \multicolumn{2}{|c|}{ Dec. } & & & \multicolumn{2}{|c|}{ Nov. } & \multicolumn{2}{|c|}{ Dec. } & & \\
\hline Cont. & \multicolumn{2}{|c|}{$1.21 \mathrm{e}$} & \multicolumn{2}{|c|}{$1.20 \mathrm{e}$} & 1.2 & $\mathrm{H}$ & 1.2 & & 1.28 & $a b$ & 1.2 & $7 \mathrm{E}$ \\
\hline T1 & & & 1.3 & $a-e$ & 1.2 & G & 1.2 & & 1.33 & & 1.3 & D \\
\hline T2 & 1.3 & & 1.35 & $a-e$ & 1.3 & $6 \mathrm{~F}$ & 1.3 & $a b$ & 1.35 & & 1.3 & $4 \mathrm{C}$ \\
\hline T3 & 1.3 & & 1.5 & $a-d$ & 1.4 & $2 \mathrm{D}$ & 1.4 & & 1.37 & & 1.3 & $9 \mathrm{~A}$ \\
\hline T4 & 1.32 & & 1.6 & $a b$ & 1.4 & $3 \mathrm{C}$ & 1.2 & & 1.30 & $a b$ & 1.26 & EF \\
\hline T5 & 1.3 & & 1.4 & a-e & 1.3 & $3 E$ & 1.3 & $a b$ & 1.15 & & 1.2 & $3 \mathbf{H}$ \\
\hline T6 & 1.38 & & 1.63 & $a b c$ & 1.51 & $A B$ & 1.2 & $a b$ & 1.28 & $a b$ & 1.25 & $F G$ \\
\hline T7 & 1.3 & & 1.6 & $5 \mathrm{a}$ & 1.5 & A & 1.2 & & 1.23 & $a b$ & 1.24 & GH \\
\hline T8 & 1.3 & & 1.6 & & 1.5 & & 1.3 & & 1.37 & & 1.3 & \\
\hline Mean & 1.3 & & 1.4 & $A^{*}$ & & & 1.2 & $A^{*}$ & 1.30 & $A^{*}$ & & \\
\hline
\end{tabular}

Mean in each column, row or interaction with similar letter(s) are not significantly different at $5 \%$ level.

T1 = Algae extract at $0.2 \%$, T2 = Algae ext. at 0.4\%, T3 = Moringa leaves ext. "MLE" at 2\%, T4 =MLE at 4\%, T5 = Algae ext. at $0.2 \%+$ MLE at $2 \%$, T6 = Algae ext. at $0.2 \%+$ MLE at $4 \%$, T7 = Algae ext. at $0.4 \%+$ MLE at $2 \%$, T8 = Algae ext. at $0.4 \%+$ MLE at $4 \%$. 
Regarding phosphorus content in the leaves, table results clear that spraying trees with algae extract at $0.4 \%(\mathrm{~T} 2)$ exhibited the highest $\mathrm{P}$ content in leaves $(0.23 \%)$, meanwhile, trees sprayed with algae extract at $0.4 \%+$ moringa leaves extract at $2 \%$ (T7) and trees sprayed with algae extract at $0.4 \%+$ moringa leaves extract at $4 \%$ (T8) recorded the highest value in this respect $(0.24$ and $0.24 \%$, respectively). On the other hand, control treatment recorded the lowest value $(0.20$ and $0.21 \%)$ in both studied seasons. With regard to spraying dates results clear that treatments spraying in December gave higher value of phosphorus content in leaves $(0.22 \%)$ than sprayed in November $(0.21 \%)$ in the first season, meanwhile in the second one there are no significant differences between spraying dates. On the other contrary, concerning the interaction effect, results showed that no significant differences between the consent reaction and spraying date in both seasons of the study.

Concerning potassium content in leaves in Table (5), results show that different treatments led to significant increase in leaf content of $\mathrm{K}$ in both seasons. Spraying with algae extract at $0.4 \%+$ moringa leaves extract at $2 \%$ (T7) and spraying with moringa leaves extract at $2 \%$ (T3) produced the highest values (1.52 and $1.39 \%$ ) in the first and second seasons, respectively, while the control treatment recorded the lowest values in this respect (1.21 and $1.27 \%)$. As for spraying dates, December spray recorded the higher value (1.49\%) as compared with November one (1.32\%) in the first season, meanwhile in the second one, there was no significant difference between the spraying dates. Regarding the interaction effect, spraying trees with algae extract at $0.4 \%+$ moringa leaves extract at $2 \%$ (T7) in December and spraying with algae extract at $0.4 \%+$ moringa leaves extract at $4 \%$ (T8) also in December gave the highest values (1.65 and $1.65 \%$ ) in this respect in the first season, while in the second one, trees sprayed with algae extract at $0.4 \%+$ moringa leaves extract at $4 \%$ (T8) exhibited the highest values (1.35 and $1.37 \%)$ during both spraying dates.

\section{Fruit set and yield $\mathrm{kg} / \mathrm{tree}$}

Results presented in Table (6) reveal that, fruit set was significantly increased with all different treatments compared with the control. Untreated trees (control) had the lowest fruit set (22.27 and $15.80 \%$ ) in the first and second seasons, respectively. On the other hand, trees received algae extract at $0.4 \%+$ moringa leaves extract at $4 \%$ (T8) reached the maximum fruit set (32.46 and $24.96 \%$ ) in both seasons, respectively. In addition, the other treatments recorded intermediate values in this respect. Regard to spraying date, results showed that November spray was significantly higher than December (28.38, 21.07\% and 26.27, $20.61 \%$ for both November and December in the first and second seasons, respectively). As for interaction effect between the concentration treatments and spraying dates, results showed that treee sprayed with algae extract at $0.4 \%+$ moringa leaves extract at 4\% (T8) in December recorded higher values in this respect (33.03 and $25.52 \%$ ) in both seasons, respectively.

Regard to yield as $\mathrm{kg} / \mathrm{tree}$, results in the Table (6) reveal that all treatments significantly increased yield as $(\mathrm{kg})$ per tree than the control in both seasons. In this concern, spraying trees with algae extract at $0.4 \%+$ moringa leaves extract at $4 \%$ (T8) produced the highest yield $(\mathrm{kg})$ per tree $(32.81$ and 24.31) in the first and second seasons, respectively. On the other hand, the control trees exhibited the lowest yield in this respect (25.33 and $17.03 \mathrm{~kg}$ ) in both seasons, respectively. On the other side, the other treatments were in between range. Concerning spraying dates in the first season, spraying in November gave higher yield $(30.73 \mathrm{~kg})$ as compared with spraying in December $(27.49 \mathrm{~kg})$. On the contrary, in the second season no significant difference were found in this respect. Concerning interaction effect, spraying trees in November with algae extract at $0.4 \%+$ moringa leaves extract at $4 \%$ (T8) gave the highest value $(33.88 \mathrm{~kg})$ in the first season. However, in the second one spraying trees with algae extract at $0.4 \%$ + moringa leaves extract at $4 \%$ (T8) recorded the highest values (24.33 and $24.38 \mathrm{~kg}$ ) for both November and December, respectively.

\section{Fruit oil content and acidity}

It is clear from results in Table (7), that all different spraying treatments significantly increased oil content on dry basis than the control during both seasons. Trees sprayed with algae extract at $0.4 \%+$ moringa leaves extract at $2 \%$ (T7) gave the highest oil content (40.44 and 39.87\%) in the first and second seasons, respectively. On the other side, the control trees exhibited the lowest oil content (33.25 and $35.45 \%$ ) in both seasons respectively. Meanwhile, the other treatments were in between range. 
Table 6. Effect of foliar applications with algae and moringa leaves extracts on final fruit set and yield of Picual olives in 2017 and 2018 seasons.

\begin{tabular}{|c|c|c|c|c|c|c|c|c|c|c|c|c|}
\hline \multirow{4}{*}{ Treat. } & \multicolumn{6}{|c|}{ Final fruit set (\%) } & \multicolumn{6}{|c|}{ Yield (kg/tree) } \\
\hline & \multicolumn{3}{|c|}{2017} & \multicolumn{3}{|c|}{2018} & \multicolumn{3}{|c|}{2017} & \multicolumn{3}{|c|}{2018} \\
\hline & \multicolumn{2}{|c|}{ Spraying date } & \multirow{2}{*}{ Mean } & \multicolumn{2}{|c|}{ Spraying date } & \multirow{2}{*}{ Mean } & \multicolumn{2}{|c|}{ Spraying date } & \multirow{2}{*}{ Mean } & \multicolumn{2}{|c|}{ Spraying date } & \multirow{2}{*}{ Mean } \\
\hline & Nov. & Dec. & & Nov. & Dec. & & Nov. & Dec. & & Nov. & Dec. & \\
\hline Cont. & $20.65 \mathrm{i}$ & $23.88 \mathrm{~h}$ & $22.27 G$ & $15.70 \mathrm{i}$ & $15.90 \mathrm{i}$ & $15.80 \mathrm{H}$ & $25.00 \mathrm{~cd}$ & $25.66 \mathrm{bcd}$ & $25.33 \mathrm{~B}$ & $16.96 \mathrm{~g}$ & $17.10 \mathrm{~g}$ & $17.03 \mathrm{~F}$ \\
\hline T1 & $25.47 \mathrm{~g}$ & $24.40 \mathrm{gh}$ & $24.93 \mathrm{~F}$ & $17.97 \mathrm{~h}$ & $18.45 \mathrm{gh}$ & $18.21 G$ & $30.66 \mathrm{ad}$ & $25.67 \mathrm{bcd}$ & 28.17AB & $18.20 \mathrm{fg}$ & $18.60 \mathrm{efg}$ & $18.40 \mathrm{E}$ \\
\hline T2 & $23.80 \mathrm{~h}$ & $27.10 \mathrm{f}$ & $25.45 \mathrm{~F}$ & 20.00 ef & $20.70 \mathrm{de}$ & 20.35E & $33.00 \mathrm{a}$ & $25.00 \mathrm{~cd}$ & $29.00 \mathrm{AB}$ & $21.50 \mathrm{bc}$ & 20.40cde & $20.95 \mathrm{CD}$ \\
\hline T3 & $31.36 \mathrm{bc}$ & $23.93 \mathrm{~h}$ & 27.65D & $19.36 \mathrm{fg}$ & 19.10fgh & $19.23 \mathrm{~F}$ & $26.66 \mathrm{ad}$ & $24.66 \mathrm{~d}$ & $25.67 \mathrm{~B}$ & $18.43 \mathrm{fg}$ & 19.03 ef & $18.73 \mathrm{E}$ \\
\hline T4 & 28.23 ef & $29.25 \mathrm{de}$ & $28.74 \mathrm{C}$ & 20.73de & $21.75 d$ & 21.24D & $30.00 \mathrm{ad}$ & $27.00 \mathrm{ad}$ & $28.50 \mathrm{AB}$ & 19.60def & $21.10 \mathrm{bcd}$ & $20.35 \mathrm{D}$ \\
\hline T5 & $30.57 \mathrm{c}$ & $23.21 \mathrm{~h}$ & 26.89E & $23.07 \mathrm{c}$ & 20.10 ef & 21.58D & $32.10 \mathrm{abc}$ & $29.66 \mathrm{ad}$ & $30.88 \mathrm{~A}$ & $22.03 \mathrm{bc}$ & $21.60 \mathrm{bc}$ & 21.82BC \\
\hline T6 & $31.76 \mathrm{bc}$ & $21.17 \mathrm{i}$ & 26.47E & $24.26 b$ & 20.93de & $22.59 \mathrm{C}$ & $33.27 \mathrm{a}$ & $25.67 \mathrm{bcd}$ & $29.46 \mathrm{AB}$ & $22.07 \mathrm{bc}$ & $21.16 \mathrm{bcd}$ & 21.62BC \\
\hline T7 & $31.71 \mathrm{bc}$ & $30.45 \mathrm{~cd}$ & 31.08B & $24.21 \mathrm{~b}$ & $23.03 \mathrm{c}$ & 23.62B & $32.00 \mathrm{abc}$ & $32.33 \mathrm{ab}$ & $32.17 \mathrm{~A}$ & $21.60 \mathrm{bc}$ & $22.73 a b$ & $22.17 \mathrm{~B}$ \\
\hline T8 & $31.90 \mathrm{ab}$ & $33.03 \mathrm{a}$ & $32.46 \mathrm{~A}$ & $24.40 \mathrm{~b}$ & $25.52 \mathrm{a}$ & $24.96 \mathrm{~A}$ & $33.88 \mathrm{a}$ & $31.74 \mathrm{ad}$ & $32.81 \mathrm{~A}$ & $24.23 \mathrm{a}$ & $24.38 \mathrm{a}$ & $24.31 \mathrm{~A}$ \\
\hline Mean & $28.38 A^{*}$ & $26.27 B^{\star}$ & & $21.07 A^{\star}$ & $20.61 B^{*}$ & & $30.73 A^{*}$ & $27.49 \mathrm{~B}^{\star}$ & & $20.51 A^{*}$ & $20.67 A^{*}$ & \\
\hline
\end{tabular}

Mean in each column, row or interaction with similar letter(s) are not significantly different at $5 \%$ level.

T1 = Algae extract at $0.2 \%$, T2 = Algae ext. at $0.4 \%$, T3 = Moringa leaves ext. "MLE" at 2\%, T4 =MLE at 4\%, T5 = Algae ext. at $0.2 \%+$ MLE at $2 \%$, T6 = Algae ext. at $0.2 \%+$ MLE at $4 \%$, T7 = Algae ext. at $0.4 \%+$ MLE at $2 \%$, T8= Algae ext. at $0.4 \%+$ MLE at $4 \%$.

Table 7. Effect foliar applications of algae and moringa leaves extracts on flesh oil content and oil acidity of Picual olives in 2017 and 2018 seasons.

\begin{tabular}{|c|c|c|c|c|c|c|c|c|c|c|c|c|}
\hline \multirow{4}{*}{ Treat. } & \multicolumn{6}{|c|}{ Flesh oil content (\%) } & \multicolumn{6}{|c|}{ Oil acidity (\%) } \\
\hline & \multicolumn{3}{|c|}{2017} & \multicolumn{3}{|c|}{2018} & \multicolumn{3}{|c|}{2017} & \multicolumn{3}{|c|}{2018} \\
\hline & \multicolumn{2}{|c|}{ Spraying date } & \multirow{2}{*}{ Mean } & \multicolumn{2}{|c|}{ Spraying date } & \multirow{2}{*}{ Mean } & \multicolumn{2}{|c|}{ Spraying date } & \multirow{2}{*}{ Mean } & \multicolumn{2}{|c|}{ Spraying date } & \multirow{2}{*}{ Mean } \\
\hline & Nov. & Dec. & & Nov. & Dec. & & Nov. & Dec. & & Nov. & Dec. & \\
\hline Cont. & $33.18 \mathrm{i}$ & $33.32 \mathrm{i}$ & $33.25 \mathrm{G}$ & $35.60 \mathrm{gh}$ & $35.30 \mathrm{~h}$ & $35.45 \mathrm{~F}$ & $0.38 \mathrm{a}$ & $0.37 \mathrm{a} a$ & $0.37 \mathrm{~F}$ & $0.39 \mathrm{a}$ & $0.38 \mathrm{a}$ & $0.38 \mathrm{G}$ \\
\hline T1 & $37.16 \mathrm{~g}$ & 37.87 ef & $37.52 \mathrm{E}$ & $36.11 \mathrm{fgh}$ & $37.97 \mathrm{e}$ & 37.04D & $0.44 \mathrm{a}$ & $0.49 a$ & $0.46 \mathrm{C}$ & $0.46 \mathrm{a}$ & $0.49 \mathrm{a}$ & $0.47 \mathrm{C}$ \\
\hline T2 & $38.82 \mathrm{~cd}$ & $39.54 \mathrm{~b}$ & $39.18 \mathrm{~B}$ & $39.30 \mathrm{bcd}$ & $38.80 \mathrm{cde}$ & $39.05 \mathrm{~B}$ & $0.41 \mathrm{a}$ & $0.53 a$ & $0.47 \mathrm{C}$ & $0.41 \mathrm{a}$ & $0.55 \mathrm{a}$ & $0.48 \mathrm{C}$ \\
\hline T3 & $38.63 \mathrm{~d}$ & $37.31 \mathrm{fg}$ & 37.97CD & $38.56 \mathrm{de}$ & $36.35 \mathrm{fg}$ & 37.46D & $0.51 \mathrm{a}$ & $0.52 \mathrm{a}$ & $0.51 \mathrm{~A}$ & $0.53 \mathrm{a}$ & $0.54 \mathrm{a}$ & $0.53 \mathrm{~A}$ \\
\hline $\mathrm{T4}$ & $38.00 \mathrm{e}$ & $37.27 \mathrm{fg}$ & 37.63DE & $36.70 \mathrm{f}$ & $39.38 \mathrm{bcd}$ & $39.04 \mathrm{C}$ & $0.49 \mathrm{a}$ & $0.31 \mathrm{a}$ & $0.40 \mathrm{E}$ & $0.49 a$ & $0.37 \mathrm{a}$ & $0.43 \mathrm{E}$ \\
\hline T5 & $35.68 \mathrm{~h}$ & $35.82 \mathrm{~h}$ & $35.75 \mathrm{~F}$ & $36.17 \mathrm{fgh}$ & $36.25 \mathrm{fgh}$ & $36.21 E$ & $0.43 a$ & $0.47 \mathrm{a}$ & $0.45 \mathrm{D}$ & $0.46 \mathrm{a}$ & $0.46 \mathrm{a}$ & $0.46 \mathrm{D}$ \\
\hline T6 & $39.66 \mathrm{~b}$ & $39.30 \mathrm{bc}$ & $39.48 \mathrm{~B}$ & $40.98 \mathrm{a}$ & $38.55 \mathrm{de}$ & 39.77A & $0.25 \mathrm{a}$ & $0.56 \mathrm{a}$ & $0.40 \mathrm{E}$ & $0.39 a$ & $0.48 a$ & $0.43 \mathrm{E}$ \\
\hline $\mathrm{T7}$ & $40.94 \mathrm{a}$ & $39.93 \mathrm{~b}$ & $40.44 \mathrm{~A}$ & $39.99 \mathrm{~b}$ & $39.75 b c$ & $39.87 \mathrm{~A}$ & $0.50 \mathrm{a}$ & $0.48 \mathrm{a}$ & $0.49 \mathrm{~B}$ & $0.50 \mathrm{a}$ & $0.49 a$ & $0.50 \mathrm{~B}$ \\
\hline T8 & $37.09 \mathrm{~g}$ & $39.48 \mathrm{~b}$ & $38.29 \mathrm{C}$ & $37.98 \mathrm{e}$ & $39.39 \mathrm{bcd}$ & $39.69 \mathrm{~B}$ & $0.43 \mathrm{a}$ & $0.36 \mathrm{a}$ & $0.39 \mathrm{E}$ & $0.46 \mathrm{a}$ & $0.36 \mathrm{a}$ & $0.41 \mathrm{~F}$ \\
\hline Mean & $37.68 A^{*}$ & $37.76 A^{*}$ & & $37.93 A^{*}$ & $37.97 A^{*}$ & & $0.42 B^{\star}$ & $0.45 A^{*}$ & & $0.45 B^{*}$ & $0.46 \mathrm{~A}^{*}$ & \\
\hline
\end{tabular}

Mean in each column, row or interaction with similar letter(s) are not significantly different at $5 \%$ level.

$\mathbf{T} 1$ = Algae extract at $0.2 \%, \mathbf{T} 2=$ Algae ext. at $0.4 \%, \mathbf{T} 3=$ Moringa leaves ext. "MLE" at 2\%, T4 =MLE at $4 \%$, T5 = Algae ext. at $0.2 \%+$ MLE at $2 \%$, T6 = Algae ext. at $0.2 \%+$ MLE at $4 \%$, T7 = Algae ext. at $0.4 \%+$ MLE at $2 \%$, T8= Algae ext. at $0.4 \%+$ MLE at $4 \%$. 
Concerning spraying dates, there were no significant differences in oil content between different treatments and spraying dates in both seasons. As for interaction effect between different concentration treatments and spraying dates, it could be concluded that, trees sprayed with algae extract at $0.4 \%+$ moringa leaves extract at $2 \%$ (T7) and tree spray with algae extract at $0.2 \%+$ moringa leaves extract at $4 \%$ (T6) in November recorded the highest oil content in the first and second seasons, respectively.

Regarding oil acidity results in the Table (7) reveal that oil acidity was significantly affected by different concentration treatments and spraying dates and it range from (0.37 and $0.51 \%)$ in the first season, while in the second one it ranged between 0.38 and $0.53 \%$. However, the lowest oil acidity was found under control treatment $(0.37$ and $0.38 \%$ ) in both seasons, respectively. Meanwhile, the highest oil acidity was recorded with moringa leaves extract at $2 \%$ (T3) in the first and second seasons, respectively. As for spraying dates results clear that, spraying dates in November significantly reduced oil acidity $(0.42$ and $0.45 \%)$ as compared with December $(0.45$ and $0.46 \%$ ) in both study seasons, respectively . Regarding interaction effect, there were no significant differences in oil acidity among the different con centration treatments and spraying dates in both seasons of the study.

\section{Peroxide and iodine values}

Results in Table (8) show that, peroxide value was significantly affected by different concentration treatments and spraying dates in both seasons. However, peroxide values ranged from 3.91 to $5.34 \mathrm{meq} / \mathrm{kg}$ and 3.76 to $5.28 \mathrm{meq} / \mathrm{kg}$ in the first and second seasons, respectively. On the other hand, the lowest peroxide value $(3.91 \mathrm{meq} / \mathrm{kg})$ was obtained with trees sprayed with moringa leaves extract at $2 \%$ (T3) in the first season, while in the second one, trees spraying with moringa leaves extract at $4 \%$ (T4) gave the lowest value (3.76 $\mathrm{meq} / \mathrm{kg}$ ) in this respect. As for spraying dates, results clear that spraying in November gave higher peroxide value as compared with spraying in December (4.82 and $4.34 \mathrm{meq} / \mathrm{kg}$ ) and (4.69 and 4.36 $\mathrm{meq} / \mathrm{kg}$ ) for both November and December in the first and second seasons, respectively. Regarding, interaction effect, trees sprayed in December with algae extract at $0.4 \%$ (T2) recorded the lowest values $(3.46$ and $3.56 \mathrm{meq} / \mathrm{kg}$ ) in both seasons, respectively. Meanwhile, trees sprayed in November with algae extract at $0.4 \%+$ moringa leaves extract at $2 \%$ (T7) exhibited the highest values in this respect $(5.58$ and $5.50 \mathrm{meq} / \mathrm{kg})$ in the first and second seasons, respectively.

Table 8. Effect of foliar applications with algae and moringa leaves extracts on Peroxide value and iodine value of Picual olive oil in 2017 and 2018 seasons.

\begin{tabular}{|c|c|c|c|c|c|c|c|c|c|c|c|c|}
\hline \multirow{4}{*}{ Treat. } & \multicolumn{6}{|c|}{ Peroxide value (meq/kg oil) } & \multicolumn{6}{|c|}{ lodine value (mg/kg oil) } \\
\hline & \multicolumn{3}{|c|}{2017} & \multicolumn{3}{|c|}{2018} & \multicolumn{3}{|c|}{2017} & \multicolumn{3}{|c|}{2018} \\
\hline & \multicolumn{2}{|c|}{ Spraying date } & \multirow{2}{*}{ Mean } & \multicolumn{2}{|c|}{ Spraying date } & \multirow{2}{*}{ Mean } & \multicolumn{2}{|c|}{ Spraying date } & \multirow{2}{*}{ Mean } & \multicolumn{2}{|c|}{ Spraying date } & \multirow{2}{*}{ Mean } \\
\hline & Nov. & Dec. & & Nov. & Dec. & & Nov. & Dec. & & Nov. & Dec. & \\
\hline Cont. & $5.06 a b$ & $5.04 \mathrm{ab}$ & $5.05 \mathrm{~B}$ & $5.11 \mathrm{ab}$ & $5.09 a b c$ & $5.10 \mathrm{~B}$ & $81.14 \mathrm{~h}$ & $81.20 \mathrm{~h}$ & 81.17 I & $78.57 \mathrm{e}$ & $78.67 \mathrm{e}$ & $78.62 I$ \\
\hline T1 & $5.13 a b$ & $3.57 \mathrm{~b}$ & $4.35 \mathrm{G}$ & $5.18 \mathrm{ab}$ & $3.61 \mathrm{~d}$ & $4.39 \mathrm{G}$ & $84.21 \mathrm{c}-\mathrm{g}$ & 83.02e-h & $83.61 \mathrm{~F}$ & $83.30 a-e$ & 80.47 de & $81.88 \mathrm{G}$ \\
\hline T2 & $5.01 \mathrm{ab}$ & $3.46 b$ & $4.23 \mathrm{H}$ & $3.96 \mathrm{bcd}$ & $3.56 \mathrm{~d}$ & $3.76 I$ & $85.18 \mathrm{bcd}$ & $82.10 \mathrm{gh}$ & $83.64 \mathrm{E}$ & $85.69 a-d$ & $84.91 \mathrm{a}-\mathrm{d}$ & $85.27 \mathrm{C}$ \\
\hline T3 & $3.85 a b$ & $3.98 a b$ & $3.91 \mathrm{I}$ & $3.75 \mathrm{a}-\mathrm{d}$ & $4.01 \mathrm{bcd}$ & $3.88 \mathrm{H}$ & $84.81 \mathrm{cde}$ & $87.53 \mathrm{a}$ & 86.17 A & $86.55 a b c$ & $88.43 \mathrm{ab}$ & 87.49 A \\
\hline T4 & $4.57 \mathrm{ab}$ & $4.47 a b$ & $4.52 \mathrm{D}$ & $4.49 \mathrm{a}-\mathrm{d}$ & $4.47 \mathrm{a}-\mathrm{d}$ & $4.48 \mathrm{~F}$ & $85.59 a b c$ & $84.33 c-f$ & $84.96 \mathrm{C}$ & $81.74 \mathrm{cde}$ & $85.20 \mathrm{a}-\mathrm{d}$ & 83.47 E \\
\hline T5 & $4.53 \mathrm{ab}$ & $4.35 \mathrm{ab}$ & $4.44 \mathrm{~F}$ & $4.58 \mathrm{a}-\mathrm{d}$ & $4.44 \mathrm{a}-\mathrm{d}$ & $4.51 \mathrm{E}$ & $83.74 \mathrm{c}-\mathrm{g}$ & 82.68fgh & $83.21 \mathrm{H}$ & $82.20 \mathrm{cde}$ & $85.28 \mathrm{a}-\mathrm{d}$ & 83.74 D \\
\hline T6 & $4.90 \mathrm{ab}$ & $4.04 \mathrm{ab}$ & $4.47 \mathrm{E}$ & $4.85 \mathrm{a}-\mathrm{d}$ & $4.22 \mathrm{a}-\mathrm{d}$ & $4.53 \mathrm{D}$ & $87.12 \mathrm{ab}$ & $82.92 \mathrm{e}-\mathrm{h}$ & 85.02 B & $89.21 \mathrm{a}$ & 83.63a-e & 86.42 B \\
\hline $\mathrm{T7}$ & $5.58 \mathrm{a}$ & $5.10 a b$ & $5.34 \mathrm{~A}$ & $5.50 \mathrm{a}$ & $5.07 \mathrm{abc}$ & $5.28 \mathrm{~A}$ & $83.18 d-h$ & $84.30 c-f$ & 83.74 D & $81.25 \mathrm{cde}$ & $83.02 b-e$ & $82.13 \mathrm{~F}$ \\
\hline T8 & $4.82 \mathrm{ab}$ & $5.07 a b$ & $4.94 \mathrm{C}$ & $4.80 \mathrm{a}-\mathrm{d}$ & $4.79 \mathrm{a}-\mathrm{d}$ & $4.79 \mathrm{C}$ & $83.82 \mathrm{c}-\mathrm{g}$ & $83.20 \mathrm{~d}-\mathrm{h}$ & $83.51 \mathrm{G}$ & 83.44a-e & $79.93 \mathrm{de}$ & $81.68 \mathrm{H}$ \\
\hline Mean & $4.82 \mathrm{~A}^{\star}$ & $4.34 \mathrm{~B}^{\star}$ & & $4.69 \mathrm{~A}^{\star}$ & $4.36 \mathrm{~B}^{\star}$ & & $84.31 \mathrm{~A}$ & 83.47 B & & $83.54 \mathrm{~A}$ & 83.28 B & \\
\hline
\end{tabular}

Mean in each column, row or interaction with similar letter(s) are not significantly different at $5 \%$ level.

T1 = Algae extract at $0.2 \%$, T2 = Algae ext. at 0.4\%, T3 = Moringa leaves ext. "MLE" at 2\%, T4 =MLE at 4\%, T5 = Algae ext. at $0.2 \%+$ MLE at $2 \%$, T6 = Algae ext. at $0.2 \%+$ MLE at $4 \%$, T7 = Algae ext. at $0.4 \%+$ MLE at $2 \%$, T8= Algae ext. at $0.4 \%+$ MLE at $4 \%$. 
Concerning iodine value, in Table (8) results show that spraying different treatments led to significant increase in iodine value in both seasons. Spraying moringa leaves extract at $2 \%$ (T3) produced the highest values ( 86.17 and $87.49 \mathrm{mg} / \mathrm{kg}$ ) in the first and second seasons respectively, while the control treatment recorded the lowest values (81.17 and $78.62 \mathrm{mg} / \mathrm{kg}$ ) in this respect. As for spraying dates, November spray recorded the higher values $(84.31$ and $83.54 \mathrm{mg} / \mathrm{kg}$ ) in both seasons, respectively as compared with December. Regarding interaction effect, spraying trees with moringa leaves extract at $2 \%$ (T3) in December gave the highest values $(87.53 \mathrm{mg} / \mathrm{kg})$ in this respect in the first season, while in the second one trees sprayed with algae extract at $0.2 \%+$ moringa leaves extract at $4 \%$ (T6) in November exhibited the highest value $(89.21 \mathrm{mg} / \mathrm{kg})$ in this respect.

\section{DISCUSSION}

The present results regarding the influence of foliar application with algae and moringa leaf extracts on vegetative growth as well as number of leaves per shoot, leaf area and its mineral content are in line with those found by Eman and AbdAllah (2008), they found that the increases in vegetative growth characters caused by algae extracts may be due to the role of algae extracts as bio stimulants for plant growth and development because of presence of trace elements, organic substances like amino acids and plant growth regulators such as cytokine, auxin and gibberellins which improved vegetative growth and nutritional status. Furthermore, Jensen (2004) showed that algae extract contains many of micro elements (Co, B, Mo, Zn, Cu) as well as macro elements, gibberellins, auxins and cytokinins and when sprayed on plants improved root ability for growth and nutrient absorption and improved stem thickness, root growth and strong vegetative. Moreover, Eman and Abd-Allah (2008) found that all growth characters of superior grapevines (Leaf area, shoot length and number of leaves/shoot) were positively affected by algae extract. growth. However, the obtained results are in agreement with those of Emongor (2012), Rady et al (2013), Howladar (2014) and Rady et al (2015) who found that, the improvement in vegetative growth and leaf mineral content due to foliar sprays with moringa extract may be due to moringa leaf extract that considered as a natural plant growth stimulant where, it is a origin of zeatin (natural derivative of cytokinin), vitamins $\mathrm{E}$, proteins, ascorbates, phenols, several mineral elements and essential amino acid. Other reports have been showed that moringa extract plays as a plant hormone which enhances growth crops Rehman et al (2014).

Bashir et al (2014) revealed that moringa leaf extract significantly increased the average plant height, leaves number, number of branches of tomato plant. With regard to the improvement effect of spraying algae and morniga extract on fruit set, yield and fruit chemical properties, as well as oil content, acidity \%, peroxide and lodine values, the obtained results are in agreement with those of Thomas and Howarth (2000), who illustrated that application of MLE extract ( rich with zeaten like cytokinin) which may be induced cytokinin biosynthesis turned in maximum number of photosynthetic active leaves and that is obvious from number and area of leaves per plant which maintaining the chlorophylls in higher concentrations and reflect on plant yield. Moreover, foliar application of moringa that contains sufficient amounts of stimulant substances encouraged increasing celldivision rate, cell-enlargement, strengthens plants, eventually produces more and higher yield (Fuglie, 2000). Furthermore, Nagar et al (2006) pointed out that moringa leaves are rich by zeatin hormone that enhances plant growth. In addition, these results are in harmony with those obtained by Abd El-Motty and Abd El-migeed (2010), Ahmed et al (2014) and Adel Abed El Hamied (2014) on mango, they reported that, spraying mango trees with algae extracts alone or combined with natural plant extracts was very effective in improving fruit set, fruit retention, yield and enhanced fruit quality. Also, the same results are in harmony with those obtained by Hegab et al (2005) on citrus and Hafez et al (2013) on olive.

\section{CONCLUSION}

From the above mentioned results, generally, it could be concluded that applying algae and moringa extract on plant the considered as an environment friend are approach to improve plant growth and increase fruit set, yield and fruit chemical properties. However, it could be concluded that all spraying treatments at different concentrations and dates had a positive effect on increasing vegetative growth, leaf mineral contents, fruit set, yield and improving fruit chemical properties as compared with the control of Picual olive trees. Treatments of algae extract at $0.4 \%+$ moringa leaves extract at $2 \%(\mathrm{~T} 7)$ and algae extract at $0.4 \%+$ 

mineral contents, yield and chemical fruit quality of Picual olive trees

moringa leaves extract at $4 \%$ (T8) were the most effective treatments to increase vegetative growth, improve leaf mineral content, fruit set, yield and oil content. Thus, these treatments can be recommended for commercial use under similar conditions.

\section{REFERENCES}

Abd El-Migeed, A.A., El-Sayed A.B. and Hassan H.S.A. 2004. Growth enhancement of olive transplants by broken cells of fresh green algae as soil application. Minufia J. Agric. Res., 29(3), 723-737.

Abd El-Motty, E.M.H. and Abd El-Migeed M.M., 2010. Effect of algae extracts and yeast application on growth, nutritional status, yield and fruit quality of Keitte mango trees. Agric. Biol. J. N. Am. (3), 421-429.

Abdel-Mawgoud, A.M.R., Tantawy A.S., Magda M. Hafez and Hoda A.M. Habib. 2010. Seaweed extract improves growth, yield and quality of different watermelon hybrids. Research Journal of Agriculture and Biological Sciences, 6 (2), 161-186.

Adel Abed El-Hamied S. 2014. Improving growth and productivity of "Sukkary" mango trees grown in North Sinai using extracts of some brown marine algae, yeast and effective microorganisms. 1-Mineral content of leaves and fruit growth aspects. Middle East J. of Agriculture Research, 3, 318-329.

Ahmed F.F., Kamel M.K. and Ibrahim H.I.M., 2014. The synergistic effects of using plant extracts and salicylic acid on yield and fruit quality of Keitte mango trees. Stem Cell, 5, 30-39.

Ahmed, F.F. and Morsy M.H. 1999. A new method for measuring leaf area in different fruit species. Minia J. Agric. and Develop., 19, 97105.

Banat F., Pal P., Jwaied N. and Al-Rabadi A. 2013. Extraction of olive oil from olive cake using soxhlet apparatus, Amer. Jour. of Oil and Chem. Tech., 4(1), 1-8.

Bokil, K.K., Mehta V.C. and Datar D.S., 1974. Seaweeds as manure: II pot culture manorial experiments on wheat. Phykos, 13(1), 1-5.

Brown, J.D. and Lilleland D. 1946. Rapid determination of potassium and sodium in plant material and soil extract by flame photometer. Proc. Amer. Soc. Hort. Sci., 48, 331-346.

Chapman, H.D. and Pratt P.E. 1961. Methods of analysis for soil, plant and water. Univ. of Calif., Davis, Division of Agric. Sci., pp 1 -309.
Dieffenbacker A. and W.D. Pocklington. 1992. Standard methods for analysis of oils, fats and derivatives. $7^{\text {th }}$ Ed. Oxford Blackwell scientific puplications, London, UK, $1^{\text {st }}$ supplement to the, pp 1-151.

El-Sharony, T.F., El-Gioushy S.F. and Amin O.A. 2015. Effect of foliar application with algae and plant extracts on growth, yield and fruit quality of fruitful mango trees Cv. Fagri Kalan. J. Horticulture, 2, 162-168.

Eman A. Abd El Moniem and Abd-Allah A.S.E. 2008. Effect of green alga cells extract as foliar spray on vegetative growth, yield and berries quality of superior grapevines. AmericanEurasian J. Agric. \& Environ. Sci., 4(4), 427433.

Emongor, V.E. 2012. Guidelines on good agricultural practices in the production of moringa (Moringa oleifera L). Scripta Horticulturae, 15, 115-132.

FAO. 2017. The Statistical Database (FAO STAT). Food and Agriculture Organization of the United Nations. Available in: http://faostat.fao.org [15Dec, 2018] Rome, Italy.

Fawzy Z.F., Abou El-magd M.M., Yunsheng Li, Zhu Ouyang and Hoda A.M. 2012a. Influence of foliar application by EM Effective microorganisms. amino acids and yeast on growth yield and quality of two cultivars of onion plants under newly reclaimed soil. J. Agricultural Science, 4(11), 26-39.

Fawzy, Z.F., El-Shal Z.S., Li Yunsheng, Ouyang Zhu and Omaima M. Sawan. 2012b. Response of garlic (Allium sativum, L.) plants to foliar spraying of some bio-stimulants under sandy soil condition. J. Applied Sciences Research, 8(2), 770-776.

Fuglie, L.J. 2000. New uses of moringa studied in Nicaragua: ECHO's Technical Network Sitenetworking global hunger solutions. ECHO, Nicaragua. Issue 68, available in: http://www.echonommunity.org.

Ghurbat, H.M. 2013. Effect of seamino and ascorbic acid on growth, yield and fruits quality of pepper (Capsicum annum L.). Int. J. Pure Appl. Sci. Technol., 17(2), 9-16.

Hafez O.M., Saleh M.A. and El-Lethy S.R., 2013. Response of some seedlings olive cultivars to foliar spray of yeast and garlic extracts with or without vascular Arbuscular mycorrhizal fungi. J. World Applied Sciences, 24, 1119-1129.

Hegab M.Y., Shaarawy A.M.A. and El-Saida, S.A.G. 2005. Effect of Algae extract and mono potassium phosphate on growth and fruiting of 
Balady orange trees. Under Press in Bull. Fac. of Agric Cairo. Univ. 56, 107-120.

Hernández, R.M.H., Santacruz F. and RuizLópez. M.A. 2013. Effect of liquid seaweed extracts on growth of tomato seedlings (Solanumly copersicum L.). J. Applied Phycology. Volume 26, 619-628.

Howladar, S.M. 2014. A novel Moringa oleifera leaf extract can mitigate the stress effects of salinity and cadmium in bean (Phaseolus vulgaris L.) plants," Ecotoxicology and Environmental Safety, 100, 69-75.

Jacobs, M.B. 1959. The chemical analysis of food and products. D.Van. Nostrand Company, Inc. New York, USA, pp. 380-381.

Jensen, E.M. 2004. Seaweed fact or fancy. From: The Organic Broadcaster. Published by Moses the Midwest Organic and Sustainable Education. From the Broadcaster, 12(3), 164-170.

Makkar H.P.S. and Becker K. 1996. Nutritional value and antinutritional components of whole and ethanol extracted Moringa oleifera leaves. Animal Feed Science and Technology, 63, 211-228.

Ministry of Agriculture and Land Reclamation M.A.L.R. 2016. Acreage and total production of Agric. Crops in A.R.E. Bull. Agric. Econ. and Statistics (In Arabic), 391 p.

Nagar, P.K., Iyer R.I. and Sircar P.K. 2006. Cytokinins in developing fruits of Moringa pterigosperma Gaertn. Physiol. Plant., 55, 45-50.

Pregl, F. 1945. Quantitative Organic Micro Anal. $4^{\text {th }}$ Ed. J.A. Churchill Ltd. London, 33p.

Rady, M.M., Gamal F., Mohamed A.M. and Yasmin H.M. 2015. Integrated application of salicylic acid and Moringa oleifera leaf extract alleviates the salt-induced adverse effects in common bean plants. J. Agricultural Technology, 11(7), 1595-1614.

Rady, M.M., Varma B.C. and Howladar S.M., 2013. "Common bean (Phaseolus vulgaris L.) seedlings overcome $\mathrm{NaCl}$ stress as a result of presoaking in Moringa oleifera leaf extract. Scientia Horticulturae, 162, 63-70.

Rama Rao, K. 1991. Effect of seaweed extract on Zizyphus mauratianaLamk. J. Indian Bot. Soc., 71, 19-21.
Rehman, H., Nawaz M.Q., Basra S.M.A, Afzal I., Yasmeen A. and Hassan F.U., 2014. Seed priming influence on early crop growth, phenological development and yield performance of linola (Linum usitatissimum L.). J. Integrative Agriculture, 13(5), 990-996.

Russo A., Carrozza G.P., Vettori L., Felici C., Cinelli F. and Toffanin A. 2012. Plant beneficial microbes and their application in plant biotechnology. Innovation in Biotechnology. Eddy C.A. (ed), ISBN: 978-956- 51-0096-6, In Tech. pp. 57-72.

Shabana, Abeer I., Hoda I. Ahmed, Shafeek M.R. and Faten, S. Abd El-Al. 2015. Improving the productivity of tomato crop grown under high temperature condition using some safe and natural substances. Middle East J. Agric. Res., 4(2), 154-161.

Shahzad, U., Khan M.A., Jaskani M.J., Khan I.A. and Korban S.S. 2013. Genetic diversity and population structure of Moringaoleifera. Conservation Genetics, (14), 1161-1172.

Shehata, S.M., Heba S. Abdel-Azem, Abou ElYazied A. and El- Gizawy A.M. 2011. Effect of foliar spraying with amino acids and seaweed extract on growth, chemical constitutes, yield and its quality of celeriac plant. European $\mathbf{J}$. Scientific Research, 58(2), 257-265.

Snedecor, G.W. and Cochran W.D. 1980. Statistical methods. $7^{\text {th }}$ Ed. lowa State University Press, Ames, lowa., U.S.A., 491p.

Spinelli, F., Giovanni F., Massimo N., Mattia S. and Guglielmo C., 2009. Perspectives on the use of a sea weed extract to moderate the negative effects of alternate bearing in apple trees. J. Hort. Sci. Biotechn. 17(1), 131-137.

Thomas, H. and Howarth C.J. 2000. "Five ways to stay green," J. Experimental Botany, 51, 329-337.

Wild, S.A., Corey R.B., Lyer J.G. and Voigt G.K., 1985. Soil and plant analysis for tree culture. Oxford and IBH Publishing Co., New Delhi, India, pp. 1-142.

Zodape S.T., Gupta A. and Bhandari S.C. 2011. Foliar application of seaweed sap as bio stimulant for enhancement of yield and quality of tomato (Lycopersicon esculentum Mill.). J. Scilnd Res., 70, 215-219. 
تأثير الرش الورقي بمستخلصات الطحالب و أورلق المورنجا على النمو الخضري ،المحتوى المعدني ثلأولق، المحصول وجودة الثمار الكيميائية لأثجار الزيتون البيكوال

أحمد محمد حسن 1" - نظمي عبد الحميد²- ـرحية بدير محمد عطية علي²- حسن سيد أحمد حسن 1 ـ ليلى فؤاد حجاج 1

$$
\begin{aligned}
& \text { 1. ق قسم الفاكهة- المركز القومي اللبحوث - الدقي - الجيزة - مصر }
\end{aligned}
$$

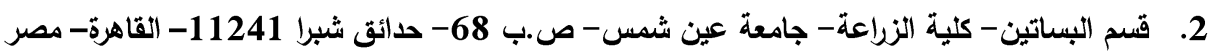

*Corresponding author: ahmed.m.hasan89@gmail.com

Received 13 January, 2019, Accepted 5 February, 2019

والمحتوى المعدني للأوراق وزيادة نسبة عقد الثمار

وكمية المحصول وصفات الثمار الكيميائية مقارنة

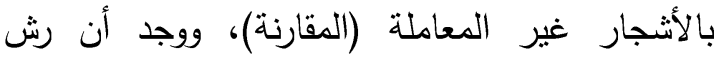

الأشجار بمستخلص الطحار غير الب بتركيز

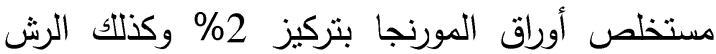

بمستخلص الطحالب بتركيز 0.4\%+ مستخلص أوكيز المورنجا بتركيز 4\% أدى إلى زياد النمو الخضري

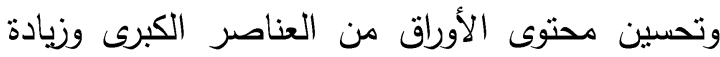

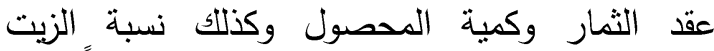

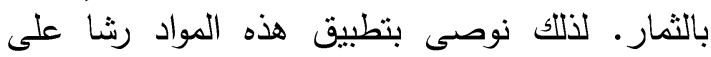
أشجار الزيتون النامية تحت نفس ظروف لنف التجربة.

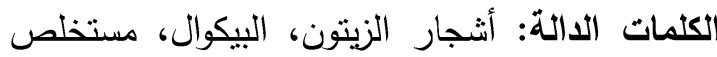
الطحالب، مستخلص أوراق المورنجا، النمو الخضري، الناك، المحتوى المعدني للأوراق، المحصول، جودة الموند، النول الثمار .

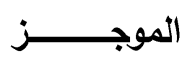

أجريت هذه الدراسة خلال عامي 2017 ، 2018 على أثجار زيتون صنف البيكوال بعمر 8 سنواتٍ بمزرعة خاصة نامية في أراضي مستصلحة حديثا بطريق القاهرة- الإسماعيلية الصحراوي بإية بدافظة الإسماعيلية - جمهورية مصر العربية. الأشجار نامية في أرض رملية وتروى بالتنقيط و متمانلة في نموها

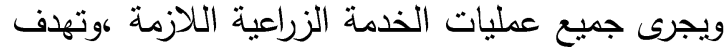

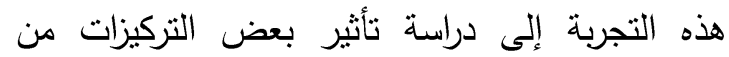
مستخلصات الطحالب وأوراق المورنجا ومواعيد الرش الترني

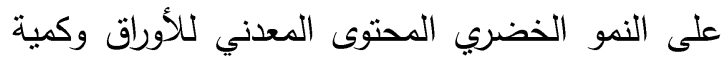
المحصول والخصائص الكيميائية لثمار أثنجار الزينون النئن

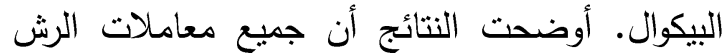

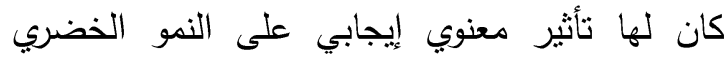

